\title{
INVESTIGATING LEXICAL ACQUISITION FOR ADULT FOREIGN LANGUAGE LEARNERS
}

\section{Riana Roos}

This paper deals with the acquisition of the lexicon of a foreign language by adult learners. The first part of the paper offers a brief overview of research on vocabulary learning and teaching; it also touches on the needs of adult language learners and the controversial question of whether vocabulary should be taught explicitly or not. The second part of the paper discusses relevant insights from cognitive psychology and language awareness studies. In conclusion, some suggestions are made on how language learning materials could be structured to promote effective lexical acquisition.

Hierdie artikel handel oor die verwerwing van die woordeskat van 'n vreemde taal deur volwasse leerders. Die eerste deel bied 'n breë oorsig oor navorsing oor die aanleer en onderrig van woordeskat; dit verwys ook na die behoeftes van volwasse leerders en die omstrede vraag of woordeskat eksplisiet onderrig moet word of nie. Die tweede deel bespreek relevante insigte verkry uit kognitiewe sielkunde en taalbewustheidstudies. Ten slotte word voorstelle gemaak oor hoe taalverwerwingsmateriaal gestruktureer kan word om effektiewe woordeskatverwerwing te bevorder.

\section{VOCABULARY LEARNING AND TEACHING: A BRIEF OVERVIEW}

\subsection{INTRODUCTION}

Vocabulary learning has become unfashionable, "the arcane mysteries of grammar acquisition" have captivated the imagination of psychologists and linguists (Bruner 1975:65). The popular view seems to be that syntax, rather than the lexicon, is complex and interesting, as is humorously illustrated by quotations such as the following:

"In the beginning was the word. But by the time the second word was added, there was trouble. For with it came syntax, the thing that tripped up so many people" (Simon 1981:111).

There are at least three strong arguments for attention to lexical learning. Once learners are past the initial stages of acquiring the second language, they identify the acquisition of vocabulary as their greatest single problem area (Meara 1980:221). Whether first, second or foreign languages are learnt by children or adults, no language learning can take place without the acquisition of lexis.

Second, some studies suggest that mother tongue speakers grade lexical errors of foreign language learners as more serious and disruptive than phonological or grammatical errors (Politzer 1978; Johansson 1978). Third, in a study of lexis in interlanguage, lexical errors were shown to outnumber grammatical errors by three or four to one (Meara 1984).

Strangely though, studies in language acquisition do not devote as much careful attention to vocabulary as to phonology or grammar. Research in this field has been described as 'unsystematic' (Meara 1980:221). In studies of learners' interlanguage, the focus tends to fall on the acquisition of morphological endings. 


\section{2}

\section{THE NEEDS OF ADULT FOREIGN LANGUAGE LEARNERS}

A survey of available materials for courses in English for Academic Purposes (Laufer 1985:1) revealed that vocabulary instruction is given considerably less emphasis than discourse-cohering devices and reading strategies. Both the selection and the practice of new vocabulary items seemed insufficient. Where vocabulary check lists are provided at the end of reading texts, or lexicons are provided as reference materials, they are merely listed in alphabetical order. This practice ignores modern insights into cognitive processes relevant to lexical acquisition.

Laufer (1985:1) contends that the assumption is made that vocabulary is either familiar or, if unknown, does not have to be explicitly taught. She also suggests that much vocabulary learning can and should be done as part of the reading process. The above-mentioned assumption goes against reports estimating the second language vocabulary level of learners at the end of secondary school at between 500 (Davies, Glendenning \& McLean 1984) and 3 000 words (Israel: Ministry of Education, reported in Laufer 1985). These figures do not even approximate the $5000-10000$ vocabulary range considered necessary for the reading of academic literature (Hulstijn \& Hazenberg 1993) and are very far from a moderate native speaker's reading vocabulary of about 50000 words (Nuttall 1982). When these figures are considered, one begins to understand the frustration of adult learners in the field of vocabulary acquisition.

The plight of the language learner falls into even sharper focus when one attempts to describe what it means to "know a word". Active knowledge of a word implies knowledge of the denotative, associative and thematic categories of meaning (Leech 1981:9-24), as well as of its underlying form and of the derivations that can be made from it. Knowledge of a word also includes register constraints such as temporal, geographical and social variation. In addition, more mature use of language requires knowledge of idiomatic and metaphorical use, where meaning involves more than knowledge of the individual meanings of the constituent words.

\subsection{EXPLICIT VOCABULARY TEACHING - OR NOT?}

In the classroom, vocabulary seems to arise regardless of the chosen activity and in spite of any conscious design on the part of the teacher. Vocabulary teaching, therefore, is not neglected in terms of quantity, but rather of quality: learners are confronted with a great number of vocabulary items, which are not presented and studied in a scientifically justified way. Gairns and Redman (1986:1) remark that a "vast amount of teaching time is consumed by explanation and definition; classroom blackboards are often littered with masses of new lexical items, and students compile vocabulary word-lists that they rarely have the opportunity to practise". It is questionable whether these incidental vocabulary items are necessarily the most useful and appropriate ones for the learners.

An argument that is often used against the explicit teaching of vocabulary is that individual words are not as important as the overall context of the sentence. Therefore, learners are expected either to guess the meaning of unknown words from the context or to ignore the words they do not know and extract the general meaning from what they can understand.

Even though inference and lexical guessing by relying on the sentence context are important strategies that differentiate good from bad readers, one should keep in mind the lexical background which forms part of the learners' receptive competence, and also the specific language needs of the learners. The intention here is not at all to underplay the importance of "text-attack" strategies such as those mentioned above or to create dictionary-dependent readers; on the contrary, language teaching should aim at encouraging autonomous learning. However, if the learners are below the "threshold level" of target language competence, that is, if they have not yet mastered elementary grammar and do not possess a basic vocabulary of at least 5000 words, these strategies cannot be applied satisfactorily (Cziko 1980). As a prerequisite for comprehension of a complex academic piece of writing and for accurate 
lexical guessing, learners should have at their disposal more than rudimentary target language competence.

Focusing on the argument contained in a text also presupposes that the text does not contain more than about five per cent of unknown words (Johns 1980), which could severely hamper comprehension. Lexical guessing cannot be successfully practised when the clues themselves are contained in words that are unknown to the learners, as is often the case in academic texts (Bensoussan \& Laufer 1984). Looking up all unknown words in the dictionary is not only time-consuming but also frustrating.

Some teachers do not consider explicit vocabulary teaching necessary, since they believe that new vocabulary can be adequately learnt through exposure to extensive reading. However, comparative research on intensive and extensive reading methods indicates that intensive reading coupled with much vocabulary practice is more effective for vocabulary acquisition than extensive reading only (Laufer 1981). It seems that while extensive reading is important for vocabulary acquisition, it is insufficient on its own. Its role, therefore, is to form an extraclassroom complement to intensive reading.

\subsection{TEACHING AND LEARNING THE FOREIGN LANGUAGE LEXICON}

One traditional way of dealing with the foreign language lexicon is via rote learning. Learners were, and often still are, expected to be able to use new vocabulary items in appropriate contexts after memorizing word lists with definitions in either the first or the target language, for example:

$\begin{array}{lll}\text { 1. } & \text { gregarious } & \text { - gesellig } \\ \text { likeable } & \text { - sympathisch } \\ \text { sullen } & \text { - mürrisch } \\ \text { 2. } & \text { gregarious } & \text { - liking the company of others } \\ & \text { likeable } & \text { - pleasing; liked by others } \\ \text { sullen } & \text { - silently bad-tempered }\end{array}$

This assumption has led to a focus on mnemonic techniques, that is, techniques that are designed to assist the memory, of which the best known is the so-called 'key word' method. This method suggests associating words in the target language with phonetically similar words in the mother tongue. Research subjects taught by this method were reported to have better retention of new vocabulary items than those subjects who were taught by repetition and rehearsal methods: learners memorized long lists of vocabulary items (sixty words) and still managed to have eighty per cent correct in a subsequent test (Raugh \& Atkinson 1975; Singer 1977).

Although this evidence appears impressive, sole reliance on mnemonic techniques for vocabulary learning ignores the complex patterns of meaning relationships that are characteristic of a well-developed lexicon because they treat lexical items as discrete pairs of translation equivalents. Lexical acquisition is watered down to a model of "paired associate rote learning", as shown in examples 1 and 2, which does not do justice to the unique lexical properties of each language. In fact, there are no two languages that completely overlap in the number of concepts that are lexicalized, nor in the way in which our experiences are categorized. 
Furthermore, the experiments that were done (e.g. Raugh \& Atkinson 1975) to support the use of mnemonic techniques such as the key-word method, were not performed in a real-life language learning situation. The experiments did not involve real language learners, but volunteers, mostly with an initial vocabulary of zero, who were prepared to take part in experiments in a laboratory setting. It is not clear how far such results are generalizable to more advanced learners who tend to have very complex patterns of motivation. Another problematic aspect of this kind of vocabulary learning is that the target language key word is required to elicit the mother tongue 'equivalent'. One could not presume that words learnt in this way would automatically become part of the active vocabulary of a foreign language learner.

Despite these criticisms, some techniques can be used in a meaningful way to assist learners in their acquisition of foreign language vocabulary. (cf 2.3.1 below).

Another factor that could influence lexical acquisition, apart from the memorizing techniques that are used, is the method of presentation of vocabulary items. Three methods of structuring vocabulary in the foreign language syllabus have been widely used (Allen \& Corder, 1975:152):

i) The random method presents lexical items in lists or as the need for them may arise. This method does not attempt to assist learners in structuring their vocabulary in a way that might make the learning process more effective, such as by presenting words in use in a reading or listening text, or by grouping words according to the context in which they are mostly used.

ii) The thesaurus method presents lexical items according to a certain field of reference or theme, such as presenting descriptions of various character traits, or learning vocabulary associated with a certain theme such as travelling.

iii) According to the principle of frequency distribution, particular lexical items can be shown to occur more or less frequently as a result of measuring them either objectively with reference to a sample of texts, or subjectively according to the opinions of specialists in the field on what constitutes a reasonable probability of occurrence.

The above-mentioned methods of structuring vocabulary in the syllabus and the experiments with vocabulary acquisition techniques focus on the management of vocabulary learning. The underlying hypothesis is that the lexical input which learners receive will result in accurate and active lexical knowledge and output. However, in language learning, what goes in is not always what comes out, that is, there is a discrepancy between input and actual intake. Analysis of the regular lexical errors that are made by adult language learners (e.g. Sonaiya 1988) confirms that learners experience vast problems in differentiating between lexical items that are closely related in meaning. Even though learners might have received input in which these items are used, they still confuse these words with semantically related items.

The learning of lexical items involves a high level of interaction with input to determine what the distinguishing properties are between a newly-acquired word and other semantically related words that the learners know. An alternative to traditional modes of presenting vocabulary could be to focus on how learning takes place and on what could be done to make learning more effective, rather than on the use of sophisticated techniques that might not be all that useful to the learner in the long run.

The acquisition of vocabulary is not an instantaneous process and the method of representation of new lexical items is not the only critical variable involved. In this regard, Meara (1980: 227) remarks that, if this were the case, "then words would not be forgotten and need to be relearned. ...it seems that words are absorbed slowly over time, and that only gradually do they become fully integrated into the learner's stock of words, when he can use them with the same sort of fluency that characterizes words he uses in his native language". 
What appears to be needed, then, is a number of strategies, as highlighted by research in cognitive psychology and language acquisition research.

\section{INSIGHTS FROM COGNITIVE PSYCHOLOGY AND LANGUAGE AWARENESS STUDIES}

\section{$2.1 \quad$ INTRODUCTION}

Central to the task of internalizing a language, whether it be first or foreign, are the cognitive processes of perceiving, judging, comparing and remembering. The field of cognitive psychology has provided applied linguistics with important insights into the nature of human learning and has shed light on the active processes involved in all language learning settings, in the initial as well as in the advanced stages of learning. These processes can be described and used to assist learning and give direction to the way teaching could be structured more effectively.

Cognitive psychologists such as Ausubel (1968) have pointed out the importance of meaningful as opposed to rote learning for the retention of information in long-term memory. The first prerequisite for meaningful learning is that learners should have a meaningful learning set - that is, a disposition to relate the new information to what they already know. Another prerequisite is that the learning task has to be potentially meaningful to the learners that is, relatable to the learners' structure of knowledge. The latter implies that learners need to experience the learning process as personally enriching and indispensable for their future goals. Even when some information that has been learnt is later "systematically forgotten" through a process of "cognitive pruning", the most important items will be subsumed into the larger cognitive structure if they have been acquired in a meaningful way (Brown 1987:65$70)$.

Recent research dealing with cognitive psychology in language learning has focused on assisting learners in becoming aware of, understanding and improving their own learning processes by means of introducing and practising new learning strategies (cf O'Malley \& Chamot 1990; Rubin \& Thompson 1982; Ellis \& Sinclair 1989; Weinstein \& Underwood 1985; Jones et al. 1987; Hosenfeld et al. 1981). Instructional materials designed from this point of view fit into the framework of the movement towards greater language awareness on the side of the learner.

\subsection{DEFINING LANGUAGE AWARENESS}

Language awareness is not easily defined. In Britain, the term is particularly associated with an educational movement that initially focused on mother tongue speakers at school level only. The British National Council for Language in Education (NCLE) Working Party on Language Awareness agreed on the definition of language awareness as a "person's sensitivity to and conscious awareness of the nature of language and its role in human life" (Donmall 1985:7). As a macro-educational issue, this movement takes as its thesis the view that increasing learners' "conscious reflection on the language(s) they use will enhance the development of their human potential by making them more aware of the influence that language has on them and the influence they in turn can exercise through language" (Nicholas 1991:78).

Language awareness programmes aim at developing such awareness within three broad parameters, namely the cognitive, in terms of some heightened perception or salience; the affective or psychological which includes language attitudes; and the social, thereby relating language awareness to the connection between language choice and our understanding of the nature and function of language use in society.

Following the pioneering work of Hawkins (1987) and the publications of the NCLE, the research field of language awareness was soon extended to include foreign language learning as well as the tertiary level of education. It seems reasonable to assume that adult language 
learners could reach the desired level of foreign language competence more efficiently if insights from the fields of language awareness and cognitive psychology were incorporated into the learning process.

Such competence would also encompass more than knowledge of only one component of language, such as might be the case if a language learning programme focuses more heavily on one component, e.g. grammar, than on the others. The idea that all areas of language use should weigh equally heavily in a language learning programme is supported by cognitive linguistics, which regards all dichotomies in language, such as the opposition between lexis and syntax, as false dichotomies (Langacker 1987). Other examples of such false dichotomies are semantics vs. pragmatics, synchrony vs. diachrony, competence vs. performance, and language vs. cognition. Language awareness training could integrate successfully the teaching of all aspects of language because it concentrates on all phenomena in language and language use.

\subsection{LEARNING MATERIALS FOR ADULT LANGUAGE LEARNERS}

How could learning materials make language learners more aware of their own learning? This could be done by encouraging them to reflect on previous language learning experiences and to acquire and rehearse strategies consciously in order to become more successful language learners. This approach could challenge adult learners to exploit their cognitive abilities and make them more responsible for their own learning. Such a language awareness programme could present them with non-technical explanations of the language learning process, recommend and provide opportunities for the practice of specific learning strategies, and suggest useful learning resources.

Working within a framework of learning strategies is equally applicable to vocabulary as to grammar teaching. In fact, within such a learning programme the artificial separation between the grammar and the lexicon is less likely to persist, as has been explained. Several researchers have suggested learning strategies and activities that are organized into an instructional sequence which provide ample scope for learners to become aware of their existing mental processes and strategies, to model the strategies and to practise and evaluate these strategies. Furthermore, they lend themselves to use in all fields of study which, according to the principle of language across the curriculum, as described by the NCLE Working Party, are all "essentially different ways of using language" (James \& Garrett 1991:11).

The following are some of the cognitive, affective and social strategies that could be taught as part of a language learning programme that incorporates insights from cognitive psychology and language awareness studies. It is important to note that these three categories are not mutually exclusive: on the contrary, they complement each other. In learning, and in language learning in particular, social and affective forces are at work at the same time as the cognitive ones that usually receive priority. Language awareness work should recognize the forces emanating from these three perspectives if it is to be successful.

\subsubsection{COGNITIVE STRATEGIES}

(a) Metacognitive strategies involve identifying and reflecting on one's own successful previous learning experiences, organizing one's study approach, consciously taking advantage of diverse learning opportunities and interacting with native speakers of the target language. Learners would consciously seek out opportunities for interaction in the target language in order to practise new vocabulary items in real-life situations. Reflecting on one's language learning experiences requires the use of descriptive terms and, therefore, the necessary metalinguistic terminology could be introduced at appropriate stages.

(b) Conceptual strategies could involve the use of different techniques for memorizing and practising new language items. Some meaningful mnemonic techniques are the 
association of words with their verbal act or function, learning words by grouping them in various ways, such as in classes or thematic fields (e.g. by memorizing together grammatical classes such as nouns or verbs, or the days of the week, or, to give a simple field, memorizing words by using "natural" associations such as opposites). Using mental images and associating new words with the context in which they occur could assist learners to recall specific words. Learners could also experiment with several mnemonic techniques such as rhyming and forming various kinds of associations until they find the strategies which are most effective for them personally.

(c) Monitoring strategies encourage self-evaluation: learners identify their own areas of weakness by analysing the nature of their errors and the reasons why they are made, for instance where the semantic difference between one word and another lies. They also evaluate the effectiveness of different lexical learning strategies in their learning.

(d) Deduction, induction and transfer strategies suggest ways in which to activate new vocabulary and apply grammar rules in language production as well as to induce rules from linguistic input. Such strategies could also include "lexical disambiguation exercises" (Sonaiya 1988:187), in which semantically related words are used in various contexts to help learners discern the different nuances in meaning. Learners have to infer from context which words are the appropriate ones to use. Such exercises could bridge the gap between input and intake by supplementing exposure to language through reading or listening by raising the awareness of learners to the use of closely related lexical items.

(e) Elaboration, inferencing and substitution strategies encourage exploiting the knowledge learners already possess, guessing at unfamiliar items with the help of contextual clues, using paraphrases and synonyms as substitutes for lexical items they do not know or cannot recall, and seeking relationship and structure in language input in order to infer meaning.

(f) Planning strategies involve, for example, focusing on the main ideas of a text to get a general idea of the content by scanning the main headings first. In communication situations it could involve rehearsing expected conversational exchanges beforehand.

\subsubsection{SOCIAL STRATEGIES}

Language has an indispensable interpersonal dimension: no language learning or use takes place in a vacuum. According to Halliday (1985), each utterance can be said to carry two interwoven types of meaning, namely an ideational meaning, referring to the ideas or content embodied in the utterance, and an interpersonal meaning, relating to the connection between the participants in the language use situation.

As important as the above-mentioned socio-cognitive processes is the socio-historical context of language use. The latter includes discourse conventions and culturally or historically determined views of knowledge. Individual utterances have to be considered along with the socio-historical conventions of appropriacy for that context.

Because this sociolinguistic background of language learners shapes their understanding of a text or utterance, a Language Awareness programme could help learners to recognize that they are an active part of language - it is not an independent and prescriptive system that exists without them. Such awareness involves developing awareness of being members of one or more discourse communities, of difficulties that may arise as a result thereof, as well as of how such difficulties may be resolved.

In the classroom, learners could reflect on writing and speaking activities to develop in them the awareness of how their discourse, whether spoken or written, affects the interlocutors. Group work is invaluable for this purpose. In groups, learners could discuss anticipated 
reactions and attempt to analyse their own opinions and stereotypes which might underlie their utterances. This presupposes that learners should be informed about language attitudes and their powerful influence on individuals and communities. Learners should also be made aware of the labelling and evaluating potential which language and their own specific choices of language could have. In this way, language awareness training could help learners become socially responsible language users.

Social strategies such as asking questions for clarification in the classroom as well as in conversation with native speakers, practising target language use with other learners, playing language games, and discussing effective learning experiences and strategies could help develop such awareness. Interviewing each other and native speakers in an attempt to expose stereotypes about members of other language groups, for instance, could be an eye-opening experience.

\subsubsection{AFFECTIVE STRATEGIES}

Making personal sense of the learning experience is a crucial part of effective language learning. It is a process in which the learner should be assisted to reflect upon his own language use in order to develop his "inner speech", which is created for oneself in making sense of language and thought. This inner speech is connected to contexts and emotional responses, with the emphasis on a "personal linguistic world which is accessed during the process of its growth and development" (Grenfell 1993:6).

It is important for the learner to 'make the language his own' in this way because learning a foreign language is a stressful experience: it involves risk-taking and exposure to misunderstandings. A language awareness programme could assist learners to become confident and to realize that they should neither refrain from speaking or writing for fear of making errors, nor be discouraged by incorrect guesses, and that a certain amount of ambiguity has to be tolerated as part of the learning process.

Information on the language learning process and conscious reflection on the various steps by learners as they proceed through them could relieve the stress that inevitably accompanies language learning. Activities such as debating, discussing personal response to texts and even experimenting with poetry writing in groups or pairs could be helpful in becoming conscious of their various identities as language users.

\section{INSTRUCTIONAL IMPLEMENTATION}

It is of vital importance that teachers be trained in the field of learning strategies and language awareness, before they are expected to mediate this kind of learning and awareness to learners. Some researchers have already given valuable examples of how that could be done. Gairns and Redman (1986), for instance, dedicate the entire first chapter of their teachers' book on vocabulary teaching to language awareness activities, in which they direct teachers' attention to problems encountered by learners of English as a foreign language.

Second, the development and/or adaptation of learning materials such as core textbooks must be done. Ellis and Sinclair (1989), for example, have produced a textbook in which language and learner awareness activities play a central role.

Third, the needs of specific groups of learners have to be identified. This will enable the teacher to focus specifically on the particular language awareness domains and learning strategies that are most important for each group. The needs and interests of learners of English for Academic Purposes would differ from those of, for instance, Business English. The programme for the first group might concentrate more on the reading and writing processes, whereas the other learners might need more training in language use for business negotiation purposes. 
Researchers need to take note of the level of language proficiency at which education in language awareness and learning strategies could and should be introduced (cf O'Malley \& Chamot 1990:151-184).

Changing from a teacher-centred to such a learner-centred approach to language learning has profound implications for the training of language teachers. The way in which individuals process information must be considered along with the way in which teachers teach if we are to understand and improve the instructional process. The approach to foreign language teaching and learning which is suggested here presupposes a thorough knowledge and understanding on the part of the teacher not only of the nature of the various domains of language, cognitive processes and learning strategies, but also of the development and use of instructional materials based on the suggested strategies.

Extensive training is necessary to familiarize teachers with this approach, to help them distinguish between learning and teaching strategies, and to integrate these strategies with the normal language teaching materials. The planning and implementation of such a teacher development programme could be one of the focal points of future research in teacher training.

\section{CONCLUSION}

Learners could become more independent when they are involved in an instructional programme in which they become aware of their own mental processes and existing learning strategies, and have the opportunity for ample practice and self-monitoring to develop procedural competence with the learning strategies and materials. The development of selfawareness and language awareness, the use of strategies for self-assessment and the setting of individual short-term aims could encourage less motivated but mature learners to become more independent and responsible for their own learning, and to seek out opportunities for using and practising the target language vocabulary in real-life and classroom contexts.

\section{REFERENCES}

ALLEN, JPB AND CORDER, SP (eds). 1975. The Edinburgh Course in Applied Linguistics. Volume 2. London: Oxford University Press.

AUSUBEL, DA. 1968. Educational psychology: a cognitive view. New York: Holt, Rhinehart \& Winston.

BENSOUSSAN, M AND LAUFER, B. 1984. Lexical guessing in context in EFL reading comprehension. Journal of Research in Reading 7.

BROWN, HD. 1987. Principles of language learning and teaching. Second Edition. Englewood Cliffs, New Jersey: Prentice Hall.

BRUNER, JS. 1975. Language as an instrument of thought. In Davies, A (ed). Problems of language and learning. London: Heinemann.

CZIKO, GA. 1980. Language competence and reading strategies: a comparison of first and second language oral reading errors. Language Learning 30.

DAVIES, A, GLENDENNING, EH \& MCLEAN, AC. 1984. The English language teaching survey of Nepal. Report prepared by a British Council/ODA Survey team and addressed to the Ministry of Education and Culture, Nepal.

DONMALL, BG (ed). 1985. Language Awareness: NCLE Reports and Papers, 6. London: CILT. 
ELLIS, G AND SINCLAIR, B. 1989. Learning how to learn English. Cambridge: Cambridge University Press.

GAIRNS, R AND REDMAN, S. 1986. Working with words: a guide to teaching and learning vocabulary. Cambridge: CUP.

GRENFELL, M. 1993. Reading and communicating in the modern languages classroom. Newsletter of the Flemish Association of Teachers of English as a Foreign Language, May, 68.

HALLIDAY, MAK. 1985. An introduction to functional grammar. London: Edward Arnold.

HAWKINS, E. 1987. Awareness of language. Revised Edition. Camb ridge: Cambridge University Press.

HOSENFELD, C, ARNOLD, V, KIRCHOFER, J, LACIURA, J AND WILSON, L. 1981. Second language reading: a curricular sequence for teaching reading strategies. Foreign Language Annals 14:5.

HULSTIJN, JH AND HAZENBERG, S. 1993. An empirical reassessment of the value of word-frequency criterium for vocabulary selection in foreign-language instruction. Paper read at the 18th International LAUD Symposium, 22-24 March, Mülheim an der Ruhr.

JAMES, C AND GARRETT, P (eds). 1991. Language Awareness in the classroom. New York: Longman.

JOHANSSON, S. 1978. Studies in error gravity: native reactions to errors produced by Swedish learners of English. Gothenburg: Gothenburg Studies in English 44.

JOHNS, T. 1980. The text and its message: an approach to the teaching of reading strategies for students of developmental administration. Mimeograph, University of Birmingham.

JONES, BF, PALINCSAR, AS, OGLE, DS \& CARR, EG. 1987. Strategic teaching and learning: cognitive instruction in the content areas. Alexandria, Virginia: Association for Supervision and Curriculum Development.

LANGACKER, R. 1987. Foundations of cognitive linguistics. Vol. 1: Theoretical prerequisites. Stanford: Stanford University Press.

LAUFER, B. 1981. Intensive versus extensive reading for improving university students' comprehension in English as a foreign language. Journal of reading 5:1.

LAUFER, B. 1985. A case for vocabulary in EAP reading comprehension materials. Duisburg: LAUD, Series C, Paper 3.

LAUFER, B. 1986. Possible changes in attitude towards vocabulary acquisition research. IRAL 24:1.

LEECH, G. 1981. Semantics: the study of meaning. Second edition. Harmondsworth: Penguin.

MEARA, PM. 1980. Vocabulary acquisition: a neglected aspect of language learning. In Kinsella, V. (ed). Language teaching surveys I. Cambridge: CUP. 
MEARA, PM. 1984. The study of lexis in interlanguage. Paper presented at the International Interlanguage Seminar in honour of Pit Corder, University of Edinburgh.

NICHOLAS, H. 1991. Language awareness and second language development. In James, C and $\mathrm{P}$ Garrett (eds). Language Awareness in the classroom. New York: Longman.

NUTTALL, C. 1982. Teaching reading skills in a foreign language. London: Heinemann Educational.

O'MALLEY, MJ AND CHAMOT, AU. 1990. Learning strategies in second language acquisition. The Cambridge Applied Linguistics Series. Cambridge: Cambridge University Press.

POLITZER, RL. 1978. Errors of English speakers of German as perceived and evaluated by German natives. Modern Language Journal 62.

RAUGH, MR AND ATKINSON, RC. 1975. A mnemonic method for learning secondlanguage vocabulary. Journal of Educational Psychology, 67.

RUBIN, J AND THOMPSON, I. 1982. How to be a more successful language learner. Boston: MIT Press.

SIMON, J. 1981. Paradigms Lost. London: Chatto and Windus.

SINGER, JG. 1977. Enjoying vocabulary learning in Junior High: the keyword method, Canadian Modern Language Review 43.

SONAIYA, OC. 1988. The lexicon in second language acquisition: a lexical approach to error analysis. Ph.D. Thesis. Cornell University.

WEINSTEIN, CE AND UNDERWOOD, VL. 1985. Learning strategies: the how of learning. In J Segal, S Chipman \& R Glaser (eds). Relating instruction to research. Hillsdale, New Jersey: Erlbaum. 